
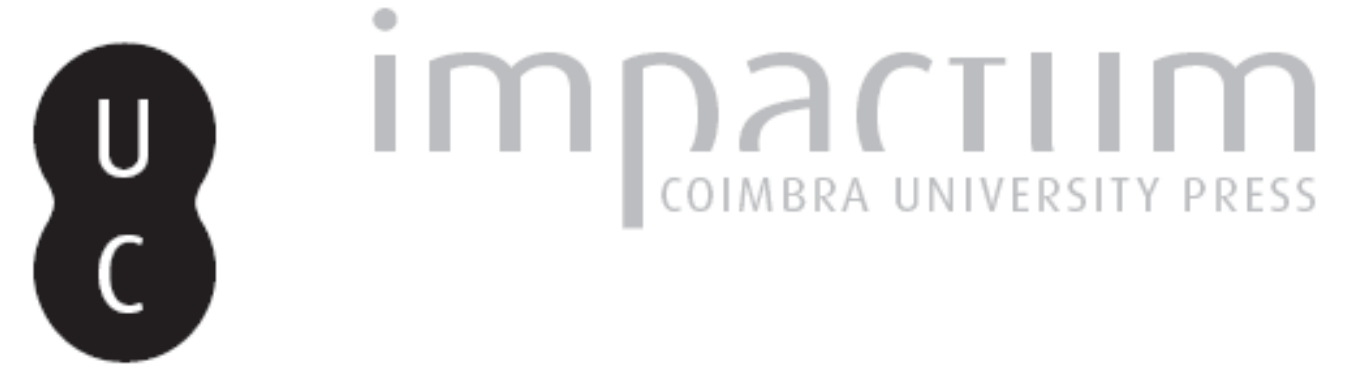

\title{
Entre o poder da arte e a arte do poder: modernismo versus neoclassicismo monumentalista na arquitectura das décadas de 1920 a $1940 ?$
}

Autor(es): $\quad$ Brites, Joana

$\begin{array}{ll}\text { Publicado por: } & \text { Instituto de História Económica e Social; Imprensa da Universidade de } \\ \text { Coimbra }\end{array}$

URL

persistente:

URI:http://hdl.handle.net/10316.2/44510

DOI: $\quad$ DOI:https://doi.org/10.14195/0870-4147_37_18

Accessed : $\quad$ 26-Apr-2023 15:16:34

A navegação consulta e descarregamento dos títulos inseridos nas Bibliotecas Digitais UC Digitalis, UC Pombalina e UC Impactum, pressupõem a aceitação plena e sem reservas dos Termos e Condições de Uso destas Bibliotecas Digitais, disponíveis em https://digitalis.uc.pt/pt-pt/termos.

Conforme exposto nos referidos Termos e Condições de Uso, o descarregamento de títulos de acesso restrito requer uma licença válida de autorização devendo o utilizador aceder ao(s) documento(s) a partir de um endereço de IP da instituição detentora da supramencionada licença.

Ao utilizador é apenas permitido o descarregamento para uso pessoal, pelo que o emprego do(s) título(s) descarregado(s) para outro fim, designadamente comercial, carece de autorização do respetivo autor ou editor da obra.

Na medida em que todas as obras da UC Digitalis se encontram protegidas pelo Código do Direito de Autor e Direitos Conexos e demais legislação aplicável, toda a cópia, parcial ou total, deste documento, nos casos em que é legalmente admitida, deverá conter ou fazer-se acompanhar por este aviso.

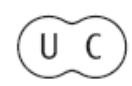




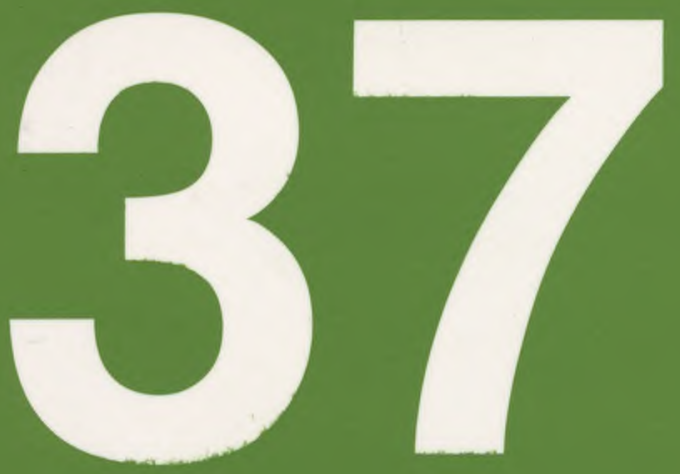

Revista Portuguesa de História

Faculdade de Letras da Universidade de Coimbra Instituto de Historia Econónica e Samial

Coimbra 05 


\section{Entre o poder da arte e a arte do poder: Modernismo versus neoclassicismo monumentalista na arquitectura das décadas de 1920 a 1940 ?}

\section{Introdução}

Encontramos no panorama arquitectónico compreendido entre os dois conflitos mundiais edifícios que, com algum consenso, se têm rotulado de «classicistas» ou «neoclássicos» por neles se reconhecerem elementos formais e/ou decorativos derivados directa ou indirectamente do Mundo Antigo. Será isto suficiente para os considerarmos neoclássicos? Onde está a "essência do classicismo"1, essa harmonia inteligível entre as partes que a tratadística e a historiografia sempre perseguiram? Qual é, afinal, o limiar mínimo a partir do qual se pode falar em classicismo?

Esta problemática dividiu, desde sempre, os que dela se ocuparam; foi objecto de polémicas, tema de teses, motivo de angústias académicas e permanece, ainda hoje, actual. Não lhe pretendemos dar resposta. As premissas de tal tentativa encontram-se envenenadas à partida porque as perguntas de que partem estão mal formuladas. Não se trata, a nosso ver, de encontrar uma grelha pseudo-científica de critérios ditos clássicos, à qual possamos submeter a arquitectura dos diversos séculos, assinalando, objectivamente, com um $x$, o cumprimento ou não dos * 
vários sine qua non. As questões que devemos e podemos, sim, levantar são: como é que cada época interpretou a arquitectura da Antiguidade? O que é que dela recuperou? De que forma? Com que finalidade?

O presente artigo procurará aplicar estas interrogações à primeira metade do século XX. Nesse sentido, após uma breve mas inevitável ponderação acerca da dimensão política da arte, analisar-se-á o «confronto» entre modernismo e neoclassicismo monumentalista travado no quadro arquitectónico internacional entre-guerras. Partir-se-á, de seguida, ao encontro da especificidade que este conflito assumiu no caso português. Finalmente, tecer-se-ão algumas considerações sobre o aparente antagonismo entre a linguagem moderna e o gigantismo neoclássico.

Far-se-á, esperamos, um capítulo da «arqueologia» do conceito de classicismo. A camada estratigráfica escolhida - o século XX - não deve causar surpresa. De facto, a partir da Antiguidade, a arquitectura de cada período histórico reagiu perante a herança greco-latina. A aparente recusa desse legado é, em si, uma significativa presença. A realidade mostra-nos que o homem precisa tanto de modelos como de anti-modelos.

\title{
2. Panorama arquitectónico entre-guerras: modernismo versus neoclassi- cismo monumentalista?
}

\author{
"Se o século de Péneles aparece materializado \\ no Partenon, a era bolchevista actual faz-se \\ representar por esses mamarrachos cubistas."
}

Adolf Hitler ${ }^{2}$

Pondo de lado as duas teses extremas - a da «arte pela arte» (absoluta independência da obra face ao contexto) e a do determinismo artístico (a capacidade da arte modificar, por si só, a sociedade) -, resta-nos a prudente consciência de que o processo criativo nunca é, quer a montante, quer a jusante, neutro. Partindo desta premissa, importa, todavia, questionar em que medida a produção artística pode ultrapassar a condição de mero reflexo do tecido sociocultural, para actuar enquanto agente de transformação do mesmo. Por outras palavras, como pode ela modificar a interpretação da realidade e, consequentemente, a acção sobre a realidade, portanto a realidade?

A resposta recai na definição, avançada por Pierre Bourdieu, de arte enquanto "sistema simbólico"; ou seja, um instrumento de conhecimento e de comunicação, uma "estrutura estruturada" e "estruturante", capaz de, à semelhança da língua

2 Cfr.A. Hitler, 1998, p. 206. 
ou da religião, unanimar os vários juízos sobre o real (tomar sensus $=$ consensus $)^{3}$. De facto, a obra artística, ao conter um discurso não só estético mas também social (o primeiro é, como vimos, indissociável do segundo), converte-se num mecanismo criador de sentido, um gerador de mundividéncias, urna fábrica de verdade(s). Ora, sendo a verdade, como Michel Foucault insistia, fruto e fonte do poder $^{4}$, a arte não escapa a ser, afinal, um dispositivo do poder que cumpre a função política de impor ou legitimar a dominação ${ }^{5}$.

Esta interacção é particularmente visível no campo da arquitectura pública. Arte do poder por excelência, soube, desde sempre, colocar o poder da arte ao serviço de objectivos bem determinados e determinantes. Independentemente do regime político vigente, esta cumplicidade está patente, isto é, a possibilidade de instrumentalização permanece em aberto. O que varia é, «tão somente», a espessura entre os limites máximo e mínimo de liberdade criativa e o grau de fruição desalienante. Por conseguinte, a arquitectura não é, por natureza, autoritária ou democrática. Simplesmente, existem formas mais ou menos autoritárias ou democráticas de produzir e de consumir a arquitectura.

Sendo este o princípio de que partimos, o período entre os dois conflitos mundiais que marcaram o século XX revela-se especialmente fértil para o testar, pôr em causa e confirmar ou não a sua validade. Com efeito, a leitura historiográfica que sobre essas décadas se tem feito tende ffequentemente a equacionar a «crise do Movimento Moderno» e a progressiva afirmação do(s) neoclassicismo(s) nos regimes autoritários ou totalitários como uma «batalha» entre «arquitectura de esquerda» e «arquitectura de direita», entre progressistas e reaccionários ${ }^{6}$, a qual se saldaria pela condenação dos primeiros a uma «marcha-atrás» arquitectónica.

Em certa medida, tal interpretação encontra suportes que a sustentam. Primeiramente, temos de reconhecer que a arquitectura moderna, condicionada por novas exigências humanas e económicas e por novas possibilidades técnicas, decorrentes da progressiva industrialização, elegeu novos imperativos estéticos (depuração formal, funcionalismo, racionalismo, repetibilidade) que não deixavam de pressupor ou postular uma reorientação da sociedade. Em segundo lugar, ao radicar numa aparente postura anti-historicista e ao defender a abstracção formal, o modernismo tomava-se incapaz de garantir a adesão das massas e a representação de um poder historicamente legitimado. Em terceiro lugar, o carácter internacional do Movimento Moderno (também conhecido por "Estilo

3 Cfr. P. Bourdieu, 1989, p. 8-10.

4 Cfr. M. Foucault, 2002, p. 12.

5 Sobre a dimensão politica da arte cfr., nomeadamente, L. J. Vale, 1992; J. Ockman, 1985.

6 Cfr. G. Argan, 1992, p. 264. 
Internacional"7), deu aso à associação que pejorativamente se estabeleceu entre o modernismo e as «ideias estrangeiras» («malignas e dissidentes»), por oposição aos elementos «puramente nacionais», considerados «genuínos e íntegros».

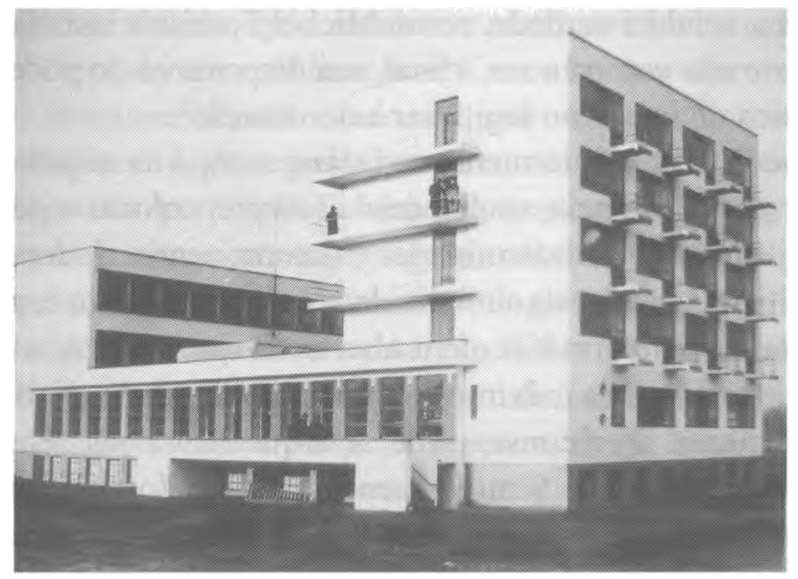

Ilustração 1 - Walter Gropius, Edifício Bauhaus, Dessau (Alemanha), 1925-1926.

[Proveniência: Judith Carmel Arthur, Bauhaus, Londres, Kliczkowski Publisher, 2000, s.p.]

Contudo, a estes três argumentos podemos, desde logo, contrapor outros três que, não os anulando totalmente, nos advertem, pelo menos, para o hibridismo do fenómeno em causa. Antes de mais, o próprio conceito de modernismo apresenta-se extremamente dúbio. Por um lado, os regimes ditatoriais não comunistas viam-no como sinónimo de arte intemacionalista, judaica e maçónica, demoliberal ou bolchevista, portanto subversiva e degradante, incapaz de expressar a realidade da Nação. Por outro lado, antes e depois da Segunda Guerra Mundial, este mesmo estilo foi encarado pelos Estados de matriz estalinista como o resultado das exigências do capitalismo ocidental, como uma arte «cosmopolita e contra-revolucionária». Representava, no seu entender, a apologia de valores «burgueses e elitistas», revelando-se inapta para agradar ao povo.

A Alemanha nacional-socialista e a União Soviética estalinista são os exemplos mais claros da materialização destas concepções. O Movimento Moderno, considerado desde o Mein Kampf como preparação do "advento do bolchevismo político"s e produto de "extravagâncias demenciais de decadentes

7 Designação avançada por Henry-Russell Hitchcock e Philip Johnson, em 1932. Sobre este assunto, cfr. J. Paul, 2003, p. 715-716.

8 Cfr. A. Hitler, 1998, p. 206. 
ou de degenerados"9, foi reprimido e preterido em favor da ressuscitação empolada das formas dóricas. Urna "arte da eternidade"10 11 que, ao apropriar-se da estética dos gregos e dos romanos, ficticiamente considerados antecedentes dos alemães, atestava a continuidade da superioridade cultural dos arianos. Por sua vez, a herança neoclássica prussiana do início do século XIX, patente na obra de Friedrich Gilly ${ }^{11}$ e Karl Schinkel ${ }^{12}$, certificaria o carácter nacional deste estilo e, novamente, a legitimidade da sua recuperação.

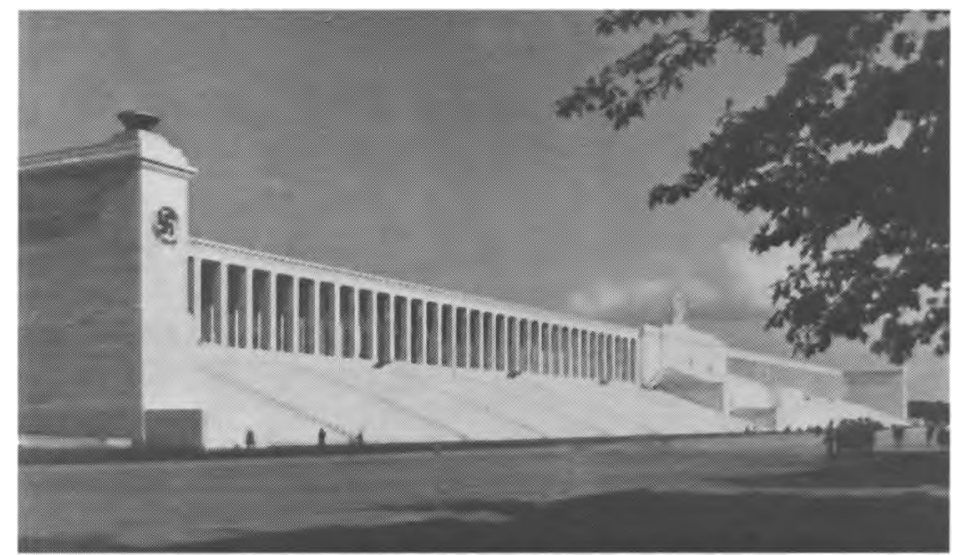

Ilustração 2 - Albert Speer, Campo Zeppelim, Nuremberga, 1936.

[Proveniência: Spiro Kostof, Historia de la arquitectura (trad. do inglês), Madrid, Alianza, 1996, vol. 3, p. 1255.]

Encerrada definitivamente a Bauhaus em 1933'3, a história da arquitectura alemã prosseguirá nos Estados Unidos da América, exílio artístico da Europa entre-guerras, e não na sua pátria, onde a julgavam incapaz quer de "formar essa «ponte de tradição» para as gerações futuras que Hitler desejava", quer de "fomentar essa heroica inspiração que Hitler sentia nos monumentos do passado"14.

A Rússia, à partida mais propensa a abraçar as vanguardas ${ }^{15}$, deslizou para o mesmo tique neoclássico ${ }^{16}$, fundamentando-o não só com o que se sentenciava ser o «vazio ideológico patente na abstracção das formas»» ${ }^{17}$, mas, sobretudo,

\footnotetext{
' Cfi-.A. Hitler, 1998, p. 203.

10 Cfr. E. Michaud, 1996.

${ }^{11}$ Cfr. H. Tintelnot, 1972, p. 37.

12 Cfr. F. Chueca Goitia, 1985, p. 203-213.

13 Cfr. W. Haftmann, 1986, p. 20.

14 Cfr. A. Speer, 1969, p. 102

15 Cfr. B.Zevi, 1970, p. 182.

16 Cfr. A. Tarkhanov, 1992, p. 44-79.

${ }^{17}$ Cfr. A. Lunatcharsky, 1975, p. 92.
} 
pelo facto de, perante as obras modernas "os proletários e os camponeses - que, tal como os grandes artistas de todos os tempos, exigem principalmente claridade à arte - se limitam [limitarem] a encolher os ombros ante este produto degradado da cultura europeia ocidentaVxi.

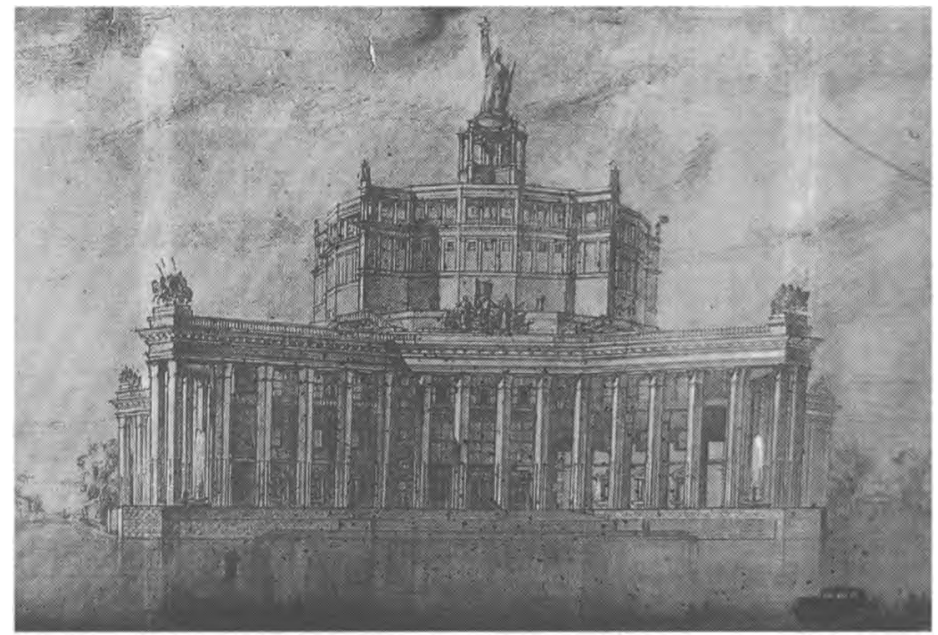

Ilustração 3 - Karo Alabyan e Vasily Simbirtsev,

Teatro do Exército Vermelho, Moscovo, 1934-1940.

[Proveniência: Alexei Tarkhanov e Sergei Kavtaradze, Stalinist architecture,

London, Laurence King, 1992, p. 71.]

Consequentemente, a procura de uma arte «acessível a todos», facilmente descodificável (ou assimilável), constituiu um argumento de peso para a opção soviética. Por detrás estava, engenhosamente, a intenção de se abafar os diversos nacionalismos artísticos que poriam em causa a sobrevivência da União Soviética. A adopção do neoclassicismo monumental conteria os particularismos regionais, afirmando, através de uma «unicidade artística», a unidade política.

Não sendo, portanto, a orientação ideológica a responsável pelo veto do Movimento Moderno, ou seja, não se tratando de um conflito entre arquitectura de esquerda e direita, tão pouco podemos querer ver nele um confronto entre arquitectura de totalitarismos e democracias. A arquitectura pública edificada entre-guerras nos EUA ${ }^{18}{ }^{19}$, em França ${ }^{20}$, no Reino Unido ou na Suécia ${ }^{21}$ bastaria

${ }^{18}$ Cfr. A. Lunatcharsky, 1975, p. 92.

${ }^{15}$ Cfr. S. Kostof, 1996, p. 1254.

${ }^{20}$ Cfr. B. Zevi, 1970, p. 202-207.

${ }^{21}$ Cfr. J. Minnaert, 2003, p. 89. 
para comprovar as semelhanças com a encomendada pelos poderes vigentes em Berlim, Roma ou Moscovo, exorcizando, de urna vez por todas, a leitura redutora que apresenta a arquitectura dos regimes autoritários ou totalitários como ilhas de neoclassicismo num mar de modernidade.

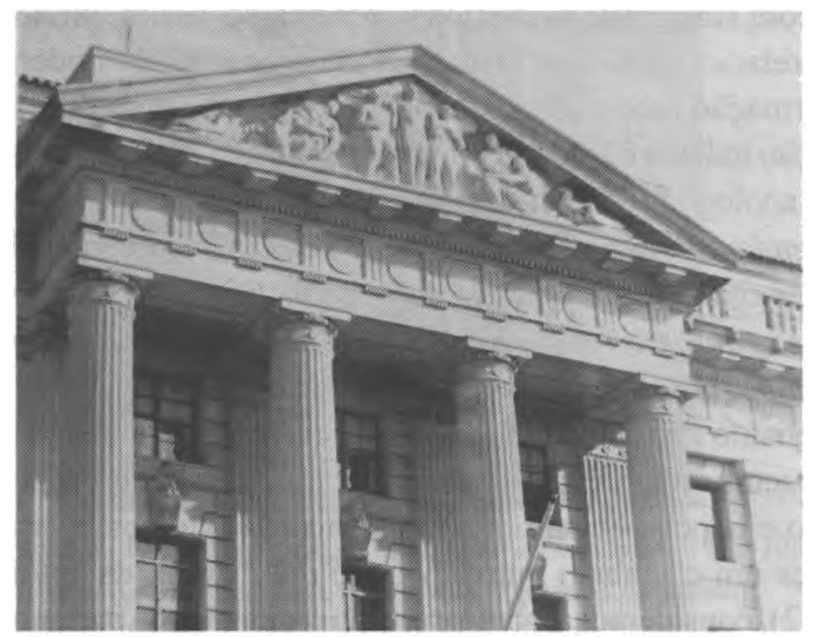

Ilustração 4 - Edward York e Philip Sawyer, Ministério do Comércio, Washington D.C., 1932.

[Proveniência: Spiro Kostof, Historia de la arquitectura (trad. do inglês), Madrid, Alianza, 1996, vol. 3, p. 1253.]

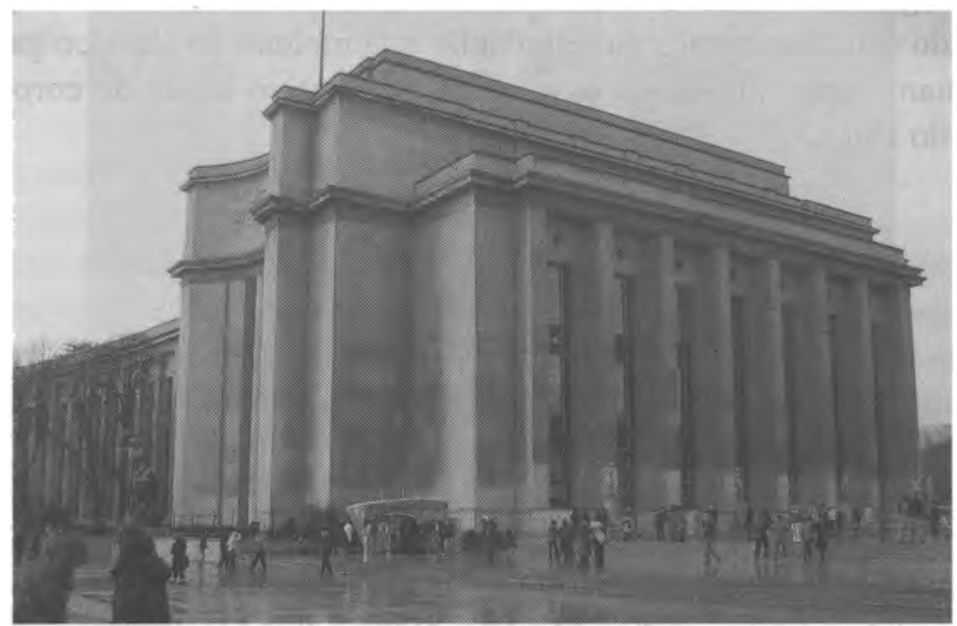

Ilustração 5 - Jacques Carlu, Louis-Hyppolite Boileau e Léon Azéma, Palais de Chaillot, Paris, 1937.

[Fotografia da autora] 
Se a «recusa» da arquitectura moderna se apresenta, como vimos, marcada pela ambiguidade das significações que a ela se «colaram», o seu aproveitamento por alguns Estados não deixa de manifestar também uma certa dualidade ou anfibiologia de objectivos e procedimentos. Com efeito, a arquitectura moderna acaba por cooperar ou ser absorvida e transformada por alguns dos regimes ditatoriais com fins propagandísticos. Verifica-se, assim, uma abertura inicial a estéticas relacionadas com conceitos de progresso e modernização, como meio de afirmação face a uma herança que esses regimes queriam superar.

A evolução italiana é a este nível paradigmática ${ }^{22}$. Benito Mussolini revela-se, desde cedo, apologista de uma "arte tradicionalista e ao mesmo tempo moderna, que deve atender ao passado e igualmente ao futuro', defendendo que, para tal, "não devemos explorar o património do passado. Devemos criar um novo património que possa equipararse ao antigo, devemos criar uma arte nova, uma arte do nosso tempo, uma arte fascista" 23 .

O paralelismo entre a velha e a nova arquitectura de Roma foi conseguido pelos arquitectos racionalistas italianos, como Terragni e Pagano, conciliando modernismo e neoclassicismo numa imbricação que nos levaria a questionar onde começa um e acaba o outro. A Casa del Faseio, da autoria de Terragni (Como, 1932), considerada a obra-prima do racionalismo italiano ${ }^{24}$, ou o Palácio da Civilização Italiana, concebido por Guerrini, Lapadula e Romano para a Exposição Universal em Roma (1942) ${ }^{25}$, são exemplos bem elucidativos dessa dupla invocação da cartilha moderna e do catálogo clássico. As formas geométricas primárias, geralmente sem adornos, a ausência quase total da coluna, o purismo lado a lado com fragmentos ou referências incompletas ao clássico garantiam essa contaminação silenciosa, esse pacto construtivo capaz de corporizar a vontade do Duce.

${ }^{22}$ Cfr. C. Jencks, 1987, p. 48-49; I. Sola-Morales, 2003, p. 153-154.

22 Cfr. U. Silva, 1975, p. 230.

${ }^{24}$ Cfr. B. Zevi, 1970, p. 246.

${ }^{25}$ Cfr. C. Jencks, 1987, p. 49. 


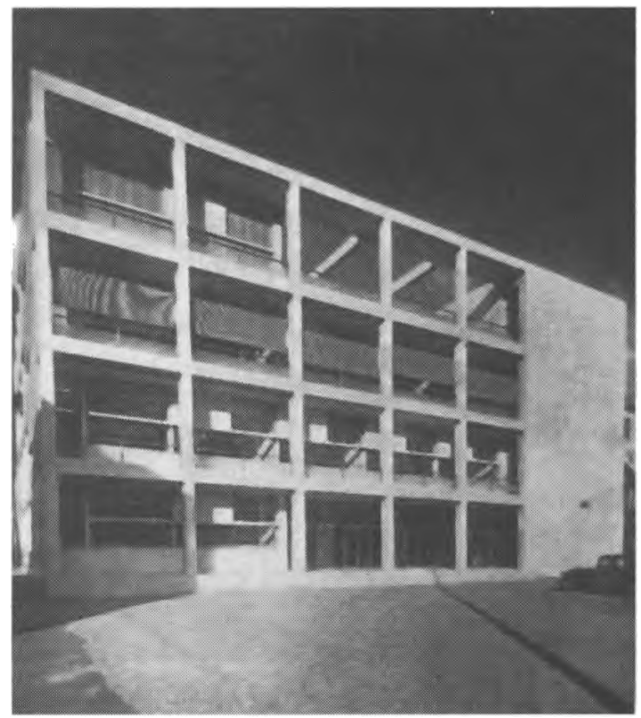

Ilustração 6 - Giuseppe Terragni, Casa del Fascio, Como, 1932-1936.

[Proveniência: Bruno Zevi, Giuseppe Terragni (trad. do italiano),

Barcelona, Gustavo Gili, 1989, 3. a edição, p. 82.]

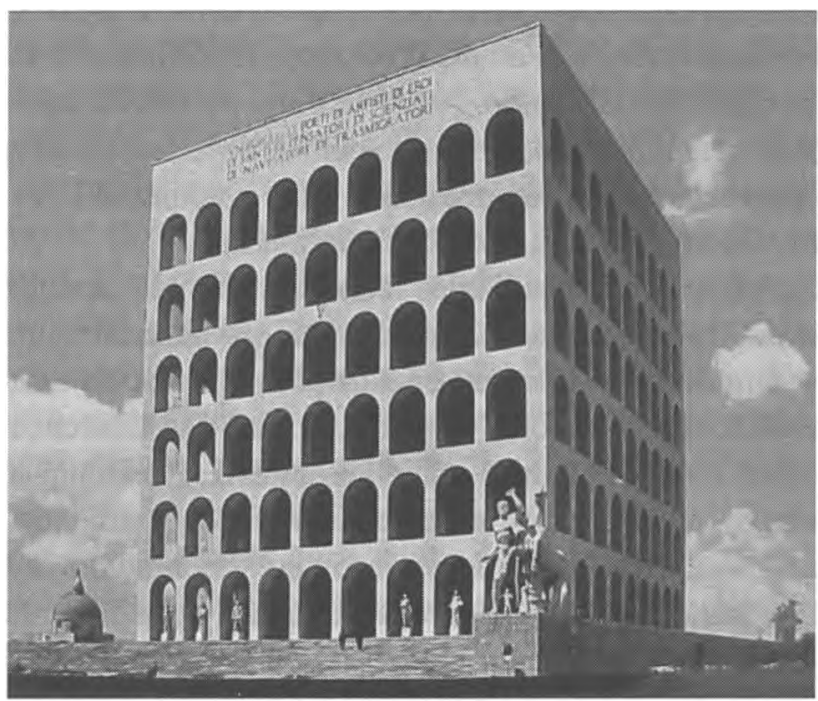

Ilustração 7 - Giovanni Guerrini, Ernesto Lapadula e Mario Romano, Palácio da Civilização Italiana, Exposição Universal de Roma, Roma, 1942.

[Proveniência: http://faculty-web.at.northwestem.edu/art-history/werckmeister] 


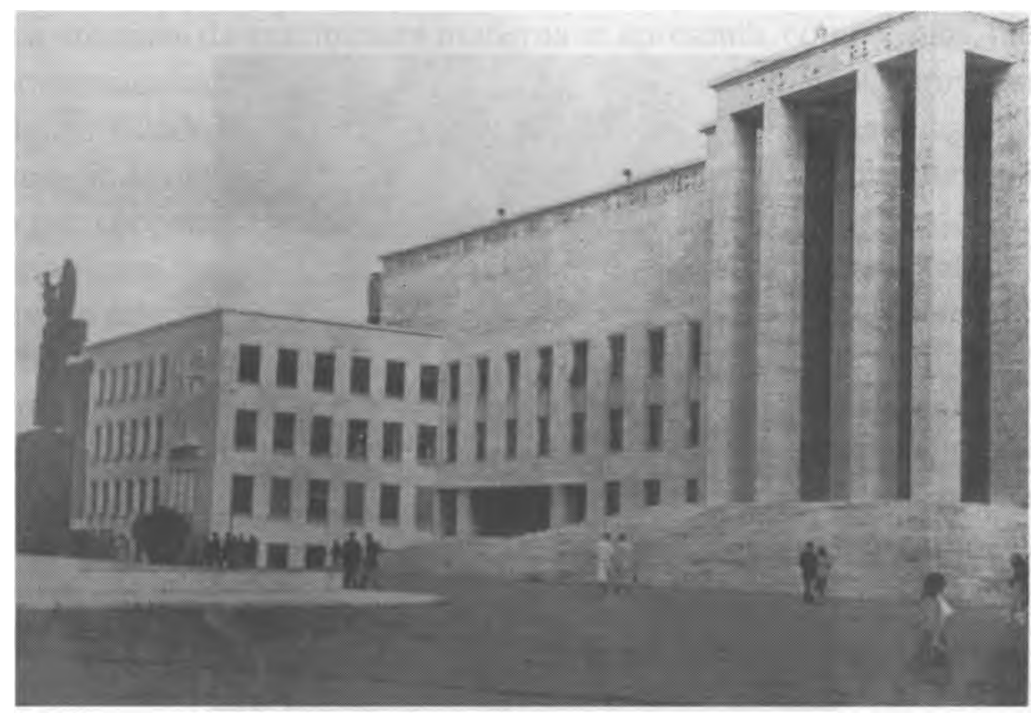

Ilustração 8 - Marcello Piacentini, Faculdade de Letras da

Cidade Universitária de Roma, 1932-1935.

[Proveniência: Maximino Correia, Ao serviço da Universidade de Coimbra: 1939-1960, Coimbra, Por ordem da Universidade, 1963, s.p.]

Devido ao insuficiente poder simbólico de que o Estilo Internacional padecia, cedo se acentua a sobrevivência do historicismo, mas de um historicismo que se queria assumir como modernizado. Neste sentido, o modernismo foi, em certa medida, reciclado ou melhorado, de acordo com os objectivos a atingir. Apropria sensação de pureza, rigor e racionalidade que o acompanhava convinha à imagem de um sistema político forte e disciplinador.

A arquitectura dos regimes totalitários soube, desta forma, capitalizar «o melhor dos dois mundos», resgatando os avanços técnicos que o modernismo conquistara e imprimindo, simultaneamente, nas construções uma escala monumental e o prestígio simbólico que a história fornecia. Apesar das diferenças existentes, as variantes arquitectónicas espelham a hibridez destes regimes: enquanto defendem o mito do moderno, pretendendo fundar uma nova ordem em que a arquitectura deve exprimir a vitalidade do presente e o seu fundamento revolucionário, exaltam, concomitantemente, as tradições nacionais, nelas filiando a sua legitimidade histórica.

Por fim, é curioso verificar que as várias arquitecturas de génese nacionalista se inserem, praticamente sem excepção, num campo formal e ideológico de dimensão internacional. De facto, identificamos em edifícios de países muitas vezes distantes e com orientações políticas distintas, a mesma marca de «gigantismo 
e autoridade», «ordem e hierarquia» que os convertia na expressão de um poder, que se pretendia irrecusável e irresistível. No fundo, na ânsia de se individualizarem recorrendo aos elementos fornecidos «pela tradição», estes regimes acabam por praticar um tipo de intervenção arquitectónica e urbana que se assemelha, inclusive em termos de vocabulário, à praticada em outros Estados. Deste modo, não deixam de professar um outro tipo de "Estilo Internacional", como, aliás, não deixariam de admitir: "Surpreendeu-me que a França se inclinasse também para o neoclassicismo nos seus edificios públicos. Tem-se afirmado muitas vezes que semelhante estilo é característico dos estados totalitários, o que não é absolutamente verdade. Pelo contrário, era sim, característico da época, deixando a sua marca tanto em Washington, Londres e Paris como em Roma e em Moscovo e nos nossos planos destinados à cidade de Berlim. "26 27

\title{
3. O papel da arquitectura moderna na afirmação do Estado Novo
}

\author{
"Para se ser utilizado é preciso demonstrar, \\ antes de mais nada, que se é útil..
}

António de Oliveira Salazar ${ }^{7}$

O cenário arquitectónico entre-guerras nos regimes autoritários e totalitários reflecte dois modelos de actuação do Estado perante as vanguardas: a sua aniquilação pela raiz, através da repressão e encerramento de centros produtores; a sua normalização e domesticação, por meio de um controlo directo (imposição) e indirecto (inculcação). Em Portugal, as décadas de 1930 e 1940 correspondem ao estruturar e consolidar do regime saído da Ditadura Militar implantada depois de 28 de Maio de 1926, o qual terá adoptado, julgamos, a segunda estratégia, aproximando-se, por conseguinte, da realidade fascista italiana.

Enquanto campo artístico melhor vocacionado para exprimir a capacidade concretizadora do poder, a arquitectura foi espelho da evolução dos pressupostos que orientaram a política cultural do regime desde 1933. Nesse sentido, ela reflecte, na sua aparente heterogeneidade estilística, os diferentes conteúdos e momentos do processo de definição e homogeneização de valores culturais. A promoção da estética vanguardista nos anos trinta corporizou a primeira etapa deste percurso porque, entre outros motivos, este se tinha de iniciar demarcando-se do capítulo político-artístico anterior.

\footnotetext{
${ }^{26}$ Cfr. A. Speer, 1969, p. 140.

27 Cfr. A. Ferro, 1933, p. 148.
} 
A criação do Ministério das Obras Públicas e Comunicações em 193228, liderado pelo Eng. ${ }^{\circ}$ Duarte Pacheco, e do Secretariado de Propaganda Nacional $(\mathrm{SPN})^{29}$ em 1933, dirigido por António Ferro, consubstanciam o quadro institucional onde se apoiou o desenvolvimento da arquitectura moderna. A "política de obras públicas" 30 , por um lado, e a "Política do Espírito" juntamente com a "política de educação nacional"31, por outro, assumiram-se como os motores material e cultural da afirmação de um Estado que se pretendia «Novo».

De facto, "a uma nova época, se essa época tem grandeza e perspectiva, deve corresponder uma nova arte"32. Era necessária "uma arquitectura nova" que imprimisse "ao País um aspecto renovado e vigoroso, que caracterizará esta época de reconstrução e a lembrará as idades futuras" 33 . Consequentemente, "não foi apenas [...] para proteger e estimular a arte moderna portuguesa" 34 que se aliciou toda uma camada recém-formada de arquitectos, justamente autodenominada "geração do compromisso"35. "O outro pensamento", como esclarecia o director do SPN, era "o da criação duma equipa de renovadores que saíssem da receita, do convencional, que contribuíssem para a elevação do nivel do nosso gosto, para acertarmos o passo, dentro e fora do País" 36 .

A percepção das vantagens que resultariam do envolvimento destas "gerações novas" naquela "hora de insofismável renovação" tinha sido bem captada por António Ferro, confessadamente apaixonado pelas ditaduras e adepto do modernismo ${ }^{37}$. Nas célebres entrevistas a António de Oliveira Salazar, publicadas no Diário de Notícias em 1932, advertia-se que "os artes e as letras foram sempre consideradas como instrumentos indispensáveis à elevação dum povo e ao esplendor

${ }^{28}$ Cfr. A. Tostões, 1996, p. 585-598.

${ }^{29}$ Denominado, a partir de 1944, Secretariado Nacional da Informação, Cultura Popular e Turismo (SNI). Sobre a sua acção, cff. J. R. do Ó, 1999.

${ }^{30}$ Cff. J. M. Femandes, 1996, p. 676-679.

31 Desenvolvida pelo Ministério da Instrução Pública cuja denominação permaneceu até 1936, quando António Carneiro Pacheco procedeu à sua alteração para Ministério da Educação Nacional.

${ }^{32}$ Cff. A. Ferro, 1949, p. 22.

33 Cff. Cadernos da Revolução Nacional [...], s.d, p. 59.

34 Cff. A. Ferro, 1949, p. 40.

35 Designação avançada por Carlos Ramos, um dos arquitectos desta geração. Esta forma-se, na sua maioria, na primeira metade dos anos vinte e abarca, além dele, Cristino da Silva, Cottinelli Teimo, Cassiano Branco, Pardal Monteiro, Gonçalo Melo Breyner, Veloso Reis Camelo, Adelino Nunes, Rogério de Azevedo, Norberto Correia, Paulino Montês e Raul Martins, entre outros.

${ }^{36}$ Cff. A. Ferro, 1949, p. 40.

" Cfr. J. R. do Ó, 1996, p. 355-357. 
de urna época. É que a arte, a literatura e a ciência constituem a grande fachada duma nacionalidade, o que se vê lá de fora..."38

Reconhecendo a "triste" situação que se vivia em Portugal neste âmbito, o futuro Presidente do Conselho e "Chefe" do Estado Novo lembrava, porém, que "so agora as circunstâncias do País nos permitem começar a pensar nesses problemas", pois "é ridículo mandar vestir casaca a um homem que não tem camisa ..." ${ }^{39}$ Contudo, o jornalista lisboeta insistía que "so é justo e necessário pensar na conservação do nosso patrimonio artístico, é igualmentejusto, e talvez mais urgente, pensar na arte viva que deve acompanhar a nossa evolução, que deve ser a expressão do nosso momento. Há aí duas dúzias de rapazes, cheios de talento e mocidade, que esperam, ansiosamente, para serem úteis ao seu País, que o Estado se resolva a olhar para eles."40 António de Oliveira Salazar, "disposto a abrir-se a todas as inovações", como diagnosticava o entrevistador, rematava então: "Estamos de acordo. O pensamento e o espirito não devem parar. Há que estimulá-los e dar-lhes um movimento contínuo. Diga, portanto, a esses rapazes que tenham confiança e saibam esperar... "41

E os arquitectos esperaram. Aprofícua colaboração proposta era por eles aguardada há muito como solução para a crise profissional que viviam, com poucas encomendas públicas e com uma «sociedade civil» que continuava a preferir os mestres-de-obras ou os engenheiros ${ }^{42}$. Acrescia a esta situação, tanto o facto de a nova geração de arquitectos enveredar por uma renovação estética sem adoptar os princípios ideológicos - democráticos ou socialistas - do Movimento Moderno internacional ${ }^{43}$; como a inexistente correspondência entre o carácter inovador dos projectos elaborados e a quase ausência de produção crítica ou teórica.

A conjugação destes factores permitiu à ditadura portuguesa "afirmar o mito da sua própria actualidade" 44 , mostrando que, perante uma "Europa desordenada, inquietante", Portugal renascia "tranquilamente, serenamente, sem atitudes teatrais". As "provas desse ressurgimento, dessa renascença, não são imagens literárias, figuras de retórica: são documentos vivos, de pedra e cimento armado, espalhados por esse País fora, ao alcance de todos. " 45

${ }^{38}$ Cfr. A. Ferro, 1933, p. 86.

${ }^{39}$ Cfr. A. Ferro, 1933, p. 87-88.

40 Cfr. A. Ferro, 1933, p. 89.

${ }^{41}$ Cfr. A. Ferro, 1933, p. 90.

${ }^{42}$ Esta situação é reconhecida pelo próprio ministro das Obras Públicas José Frederico Ulrich (1947-1954). Cfr. N. T. Pereira, 1982, p. 537.

${ }^{43}$ Cfr. N. Portas, 1984, p. 721-722.

${ }^{44}$ Cfr. A. Tostões, 1999, p. 135.

45 Cfr. Catorze anos de Política do Espírito, 1948, p. 19. 
O modernismo era, por enquanto, útil. "Os novos, os inquietos, os audaciosos" 46 tinham, pela primeira vez, uma missão. O pragmatismo deste encontro, desta efémera conveniência de ambas as partes era explicitamente evocado pelo regime. Defendia-se "audaciosamente, com irreverência oficial a arte moderna, não porque deva ser privilegiada [...], mas porque o equilíbrio da maturidade éfilho da audácia dos 20 anos, porque a arte viva se presta mais à divulgação das coisas"*I. Concomitantemente, o tom paternalista, adoptado para caracterizar a «atenção» do Estado para com os artistas, temperava a evidente instrumentalização das vanguardas. Chamando a si o dever de "proteger os homens de talento, ainda que sejam inimigos do regime"48, o Estado Novo estendia a sua mão aos artistas que mais precisavam do seu "auxílio moral e material"49, fazendo "o possivel por trazer à superficie os escondidos, os desiludidos, os amargurados, aqueles quejá nada esperavam da compreensão do Estado perante a sua ânsia legítima de renovação" 50 .

A domesticação do modernismo foi o reverso da medalha deste processo. A preferência "para os mais ousados, para os mais novos dos novos" camuflava, afinal, um mecanismo preventivo e normalizador. Como esclarecia António Ferro, "as arrumados, os académicos, os que se enfileiram e marcham são imediatamente olhados com maior simpatia pelos organismos oficiais que têm de velar-e muito bem! - pela cultura em linha recta, pela selecção daqueles valores cujo equilibrio - às vezes aparente - lhes não oferece dúvidas. Mas os outros, aqueles cujo desequilíbrio - também às vezes aparente - pode ser uma simples estrada cheia de curvas que conduz também ao equilibrio, mas a um equilibrio conseguido, sofrido, perdem-se geralmente por falta de apoio, por falta de compreensão diante da sua ansiedade, da sua impaciência, dos seus exageros muitas vezes fecundos.

Revoltados, revoltam-se ainda mais e caem, quase sempre, na loucura das formas [...]. Para evitar essa legítima revolta é que o Secretariado da Propaganda Nacional se julga no dever de os não abandonar, de seguir, atentamente, todos os seus movimentos. Este organismo do Estado, que não tem as responsabilidades culturais, por exemplo, do Ministério da Instrução Pública, quer chamar a si, em nome da ordem e do equilibrio, o modesto papel da irreverência oficial, isto é, quer representar a atenção carinhosa do Estado para com aqueles artistas de quem ele próprio desconfia ...”51

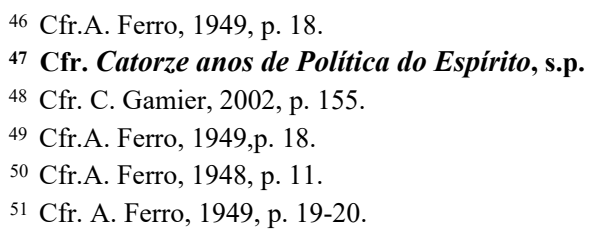


A procura da ordem não deixou, portanto, de nortear o próprio apoio à "desordem", mais superficial do que efectiva e, por isso mesmo, moldável e convertível. Cedo a novidade das formas se revelaria um argumento demasiado débil para assegurar a sobrevivência da arquitectura moderna no médio prazo. A captação por via da sensibilidade, do instinto e da recordação começaria a ganhar terreno, dando provas da sua eficácia. Antecipava qualquer análise e dispensava qualquer prova ou exercício reflexivo. A estetização da política nos anos trinta daria, assim, gradualmente lugar a uma diferente politização da arte na década seguinte.

\section{Modernismo versus neoclassicismo monumentalista em Portugal: especificidade de um "confronto»}

“O leão é feito do cordeiro que devorou."

Paul Valéry ${ }^{52}$

Nas décadas de trinta e quarenta não assistimos em Portugal a um verdadeiro «combate» teórico entre modernismo e neoclassicismo monumentalista. Raramente os modelos que recuperam a gramática clássica são objecto de comentário. É, sobretudo, ao nível da concepção e da recepção de determinadas tipologías construtivas que se encontram os contributos mais sólidos para a compreensão do neoclassicismo na produção arquitectónica do Estado Novo. De facto, as discussões, os debates, os textos mais ou menos apaixonados que então se publicaram em jornais, livros e revistas da especialidade ${ }^{53}$, centravam o confronto entre o «moderno» e o «nacional», não correspondendo nenhum deles, pese embora a nebulosidade que os envolvia, à estética clássica.

A análise dos testemunhos impressos relativos a este período relativiza a ideia, geralmente aceite, de que o modernismo foi rejeitado em bloco e, consequentemente, contido ou asfixiado. Bem pelo contrário, reconheceu-se nele "a lógica reacção indispensável e de salutar, contra os intoleráveis bonecos académicos que dominavam ainda a Arte numa tirania odiosa"54; a "reacção natural contra a desordem, contra o falso pitoresco [...] das construções do século passado e do começo deste" "55. Chegou mesmo afirmar-se que, não tendo Vignola e Vitrúvio "arrematado" para sempre a perfeição ou o bom gosto, "a revolta de muitos

»Cfr. P. Valéry, 1994, p. 70.

53 Cfr., nomeadamente, as revistas Arquitectura e A Arquitectura Portuguesa relativas ao período de 1930-1948.

54 Cfr. S. P. Júnior, 1936, p. 77.

55 Cfr. J. C. Teimo, 1936, p. 24. 
que cultivam as artes e combatem o modernismo, mantendo o pensamento congelado do passado, [...] é o combate que é preciso dar à rotina, o esforço para avançar sem a muleta dos módulos, regras e sistemas consagrados, e o medo da sua Musa lhe não dar inspiração para compor e produzir, sem tutorias" ${ }^{6}$.

É, na verdade, o carácter internacional do Movimento Moderno que mais se critica, ou seja, a "tendência para o formalismo, criando uma espécie de tipo ou padrão de edificio moderno"57, a "pseudo arte de tipo internacional, sem clima próprio, [...] o mesmo cliché já cediço, intolerável, [...] que repugna à nossa sensibilidade, à nossa raça lusíada" $5 *$. Denuncia-se o "falso espírito moderno" que nada mais reflecte "do que uma forma proletária de sentir [...], do que a marcha, marcha atrás, para o tristemente uniforme, para o monótono"59; o ir "copiar o que os outros lá por fora fazem" 60 , responsável pela "desnacionalização arquitectónica" patente na proliferação dos "caixotes de Moscovo, de Munique, de toda a parte menos de Portugal"'6'.

Não se deixava, portanto, de defender que "agora já que estamos no século $X X$, façamos arquitectura do século $X X$ "62 63 64; de esclarecer que "não somos inimigos do modernismo, porque era tolice, porque era erro, porque era visão retrógrada em vez de forte visão contemporânea ser contra o progresso no que ele traz de aquisições e de possibilidades novas"65. Mas o internacionalismo na arquitectura, "esse devia ser proibido, superiormente, se não houvesse já razões de ordem técnica e material para ser condenado. " $6 *$

Insistindo-se que "a Arte é um produto do meio"65 e que "tem de ser a mais alta expressão duma nacionalidade" 6667 , reclamava-se, por conseguinte, "o moderno, sim, mas o moderno característico da nossa paisagem, do nosso sentimento e viver"61. Propunha-se um equilíbrio que não impusesse nem "o nudismo absoluto, nem o nacionalismo sentimental" 68 , um «aportuguesamento» do modernismo a fim de manter "a sensibilidade, o poder criador, o sentido português"69.

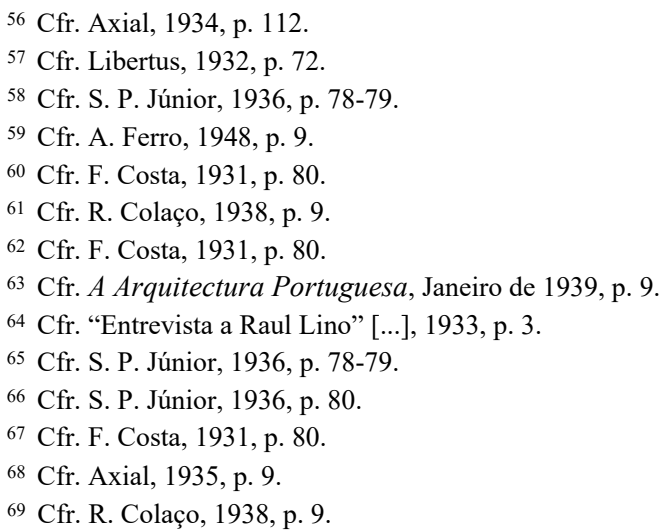


Tratar-se-ia de um tipo de construção "que esteja dentro da nossa época, mas, simultaneamente, dentro da nossa raça e do nosso clima"70 7172 . Célebre ficaria o «grito» que, sintetizando todas estas vozes, bradava: "FAÇAM-SE CASAS PORTUGUESAS EM PORTUGAL!'"11

O que se avizinha é, como podemos inferir, um desenlace de compromisso, o qual partirá do moderno, retirará dele o que interessar e transformá-lo-á em algo de diferente. As apátridas estruturas arquitectónicas foram então cobertas por soluções formais e/ou decorativas ditadas pela ocasião, pelo programa do edifício e pelo local a que se destinava; foram escolhidas entre um «receituário» linguístico onde se incluíam o revivalismo manuelino, joanino ou pombalino, o eclectismo nacionalizante da «casa portuguesa»e até mesmo a sintaxe classicizante. Um modus operandi bem caracterizado na crítica tecida por Cottinelli Teimo, no I Congresso Nacional de Arquitectura, ao declarar que "perante o problema do portuguesismo" mais não se fez do que procurar "imitações, estilizações de tudo o que de superficial, exterior [...] revela o passado", "criar afinidades de elementos decorativos e apor símbolos"11.

A variedade de hipóteses estilísticas presentes na arquitectura salazarista não isola a ditadura lusa no contexto europeu de entre-guerras. Com efeito, a reedição dos modelos clássicos nos casos alemão, russo, italiano ou até espanhol corporizou apenas uma das fórmulas exploradas. Se, na realidade, foi a mais evidente, isso deve-se ao facto de ter havido uma «nacionalização» do neoclassicismo mais forte nesses Estados do que em Portugal. Mas, de forma alguma, se tratou de uma opção exclusiva.

$\mathrm{Na}$ Alemanha exigiu-se para a vida privada um ambiente pré-industrial e bucólico, um romantismo do "imutável e convencional"73. Em Espanha, predominaram, na arquitectura residencial, os valores tradicionais e a nostalgia ruralista74. A URSS seguiu os modelos "folclórico-provincianos" na «arquitectura comum ${ }^{75}$. Em Itália acentuaram-se "os sabores locais, as cores provincianas, a anedota ornamental, o rançoso sentimentalismo do pitoresco folclórico" 76 nas construções menos representativas.

\footnotetext{
70 Cfr. Entrevistas de António Ferro a Salazar, 2003, p. 134.

71 Cfr. A Arquitectura Portuguesa, Janeiro de 1939, p. 9.

72 Cfr. J. C. Teimo, 1948, p. 62.

73 Cff.A. Cirici, 1977, p. 39.

74 Cfr. A. Cirici, 1977, p. 45-47.

75 Cff.B.Zevi, 1970, p. 198.

76 Cff.B.Zevi, 1970, p. 209.
} 
A colossalidade neoclássica adoptada nos mais imponentes edifícios públicos constituiu, como se depreende, um dos modos de o poder falar através da arquitectura. A outros se recorreu consoante o destinatário e a mensagem a transmitir. Podemos, por conseguinte, afirmar, um pouco polémicamente, que a arquitectura dos totalitarismos foi bem mais fúncionalista que o próprio racionalismo moderno, pois soube adaptar, com invejável mestria, a forma do edifício à função que este viria a desempenhar no discurso político e ideológico do regime.

Em Portugal, o «rótulo» neoclássico na arquitectura estadonovista circunscreveu-se, no essencial, a determinados modelos construtivos, como as «cidades universitárias» de Lisboa e Coimbra ${ }^{77}$, os tribunais ${ }^{78}$ e as filiais da Caixa Geral de Depósitos. O invólucro destas tipologías aproximou-se do discurso estético dos arquitectos ao serviço de Benito Mussolini, num acordo entre modernismo e elementos clássicos estilizados. A depuração dos volumes conviveu, aqui, com fiadas de janelas simétricas, pilastras e arcos redondos adossados ou com a colunata embutida ou preponderante.

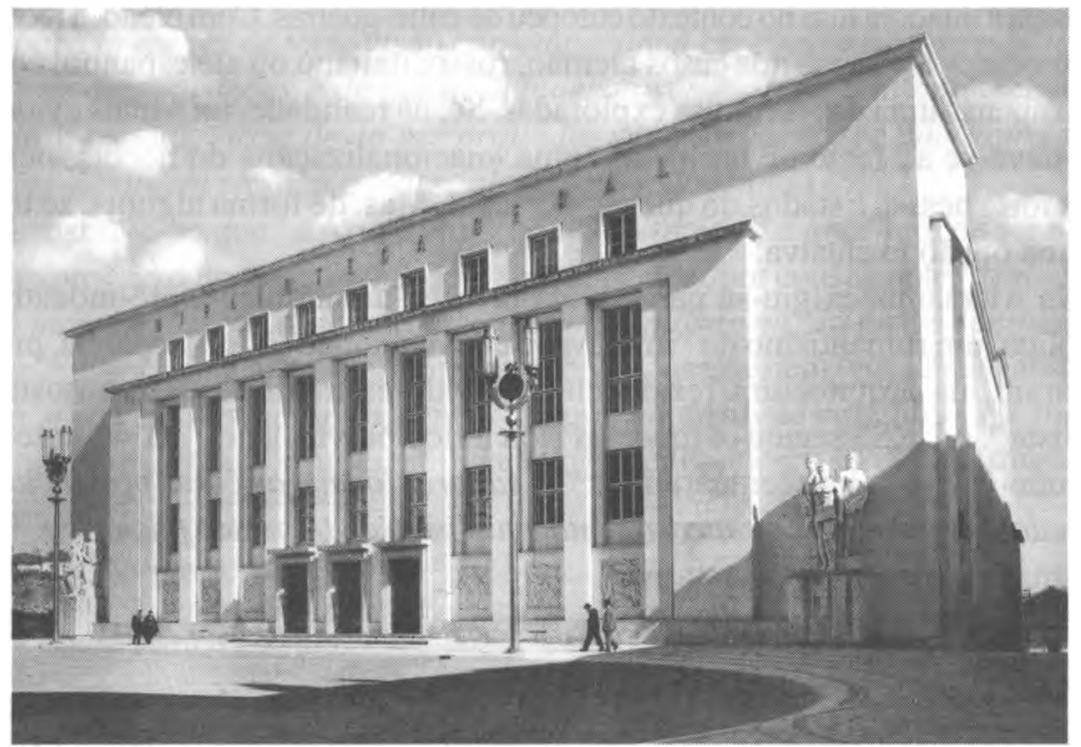

Ilustração 9 - Alberto José Pessoa, Fachada principal da

Biblioteca Geral da Universidade de Coimbra, 1944-1952.

[Proveniência: José Manuel Femandes, Português Suave. Arquitecturas do Estado Novo, Lisboa, IPPAR, 2003, p. 103.]

${ }^{77}$ Cfr. N. Rosmaninho, 1996; N. Rosmaninho, 2001.

${ }^{78}$ Cfr. A. M. Nunes, 2003. 


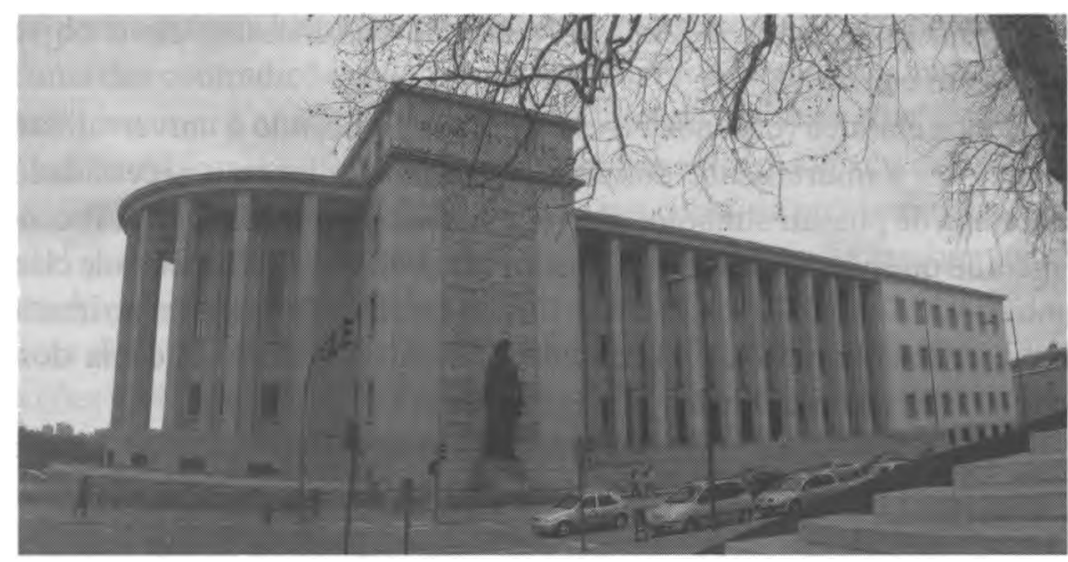

Ilustração 10 - Raul Rodrigues Lima, Palácio da Justiça do Porto, 1961.

[Fotografía de Luís Gama Pereira]

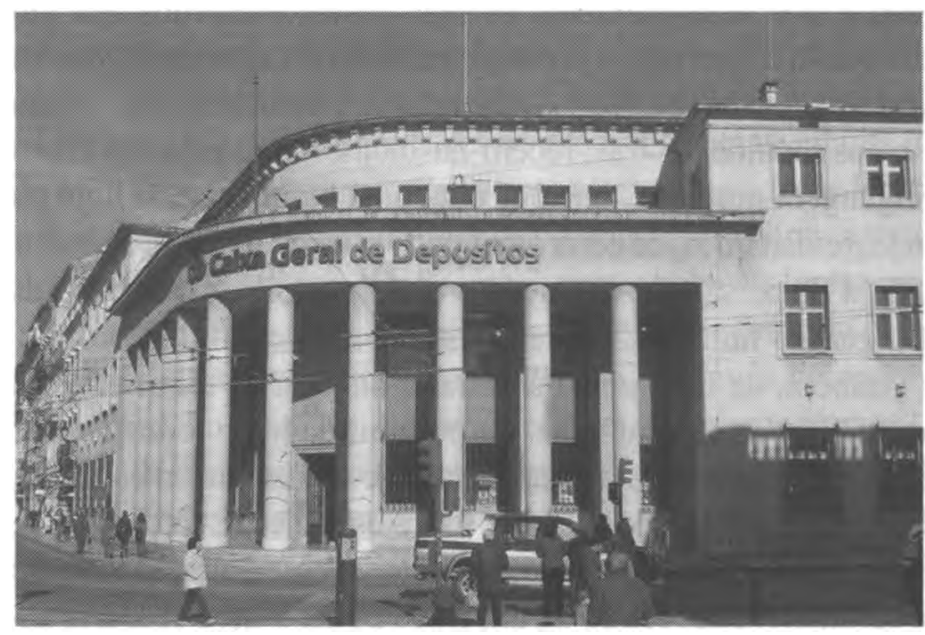

Ilustração 11 - Veloso Reis Camelo, Caixa Geral de Depósitos de Coimbra, 1948.

[Fotografía da autora]

Este aproveitamento do formulário clássico inscreve-se, como procurámos demonstrar, num fenómeno de dimensão internacional cuja unidade se baseia na forma e não no conteúdo. Diversas foram as «razões patrióticas» evocadas para a recuperação e, em certos casos, a nacionalização do «modo antigo». Como denominador comum - ponto cuja busca se toma obrigatória mas que atraiçoa a complexidade da questão - encontramos o propósito de conferir monumentalidade e dignidade ao edifício. Uma arquitectura austera, sólida, impositiva, capaz não só de conceder visibilidade e legitimidade ao encomendante, 
mas também de garantir a rendição e adesão das massas: eis o objectivo semiótico em causa.

A estética clássica respondeu a este anseio, oferecendo a universalidade do seu prestígio e a imortalidade dos seus valores. Solucionou a necessidade que o poder tinha de possuir símbolos, de ver a sua imagem reconhecida. Preencheu algo mais do que necessidades funcionais, provando que a racionalidade clássica, ao contrário do racionalismo moderno, tinha a capacidade de apelar ao irracional. Mostrou, em suma, não só a actualidade, como a enorme eficácia dos três princípios vitruvianos: utilitas, firmitas e venustas.

\section{Conclusão}

A história da arquitectura apresenta, muitas vezes, a imagem de uma «guerra» entre linguagens. Tem os seus vencedores e vencidos, os seus confrontos e as suas tréguas e, por vezes, também os seus pactos e acordos. Há línguas que, embora «mortas», conservam o prestígio inabalável dos tempos. Assim acontece com o classicismo, uma das poucas línguas que verdadeiramente se codificaram no decurso dos séculos. Outras, recém-nascidas, lutam pela sua afirmação. E o caso da linguagem moderna, que enfrenta uma batalha ainda hoje por decidir.

No fundo, revisitamos, de certa maneira, o mito da Torre de Babel: a confusão de línguas e a dispersão dos homens pretende explicar a ruptura da unidade original do género humano. $\mathrm{O}$ medo da incomunicabilidade com o próximo atravessa também, de uma ponta à outra, a história da arquitectura e explica, em última análise, as suas utopias - a possibilidade de todos falarem uma só língua - e os seus insucessos - a incapacidade de se fazerem entender. Permite-nos compreender, por isso, a razão pela qual todos os projectos totalitários recorreram ao formulário arquitectónico clássico, o qual «dispensa tradução», e o motivo pelo qual o modernismo, padecendo de um fraco poder simbólico, entrou em crise.

As dificuldades que o Movimento Moderno enfrentou assumiram proporções internacionais e não são, de modo algum, uma especificidade portuguesa, nem tão-pouco um fenómeno exclusivo de regimes autoritários ou totalitários. Prendem-se, na verdade, com as características das sociedades dessa conturbada primeira metade do século $\mathrm{XX}$, as quais não desejavam, ou não podiam desejar - dada a falta de chaves interpretativas - a «insegurança» que a radical ruptura das formas representava. Assiste-se a mais uma etapa da evolução do secular e ambíguo "par antigo/modemo"79, cuja análise diacrónica e sincrónica nos alerta 
não só para a própria historicidade do anti-historicismo das vanguardas ${ }^{80}$, como para urna das contradições intrínsecas à modernidade: mesmo quando vive das e para as massas, é apenas dominada e produzida por uma elite ${ }^{81}$.

A contenda entre modernismo e tradição, entre os apologistas da «tábua rasa» e os defensores dos «valores tradicionais», que constitui precisamente a reacção cultural generalizada a que este período assiste, reflectiu-se também na arquitectura. Ao «choque» da novidade juntaram-se as críticas decorrentes das debilidades técnicas de uma experiência recente e ainda não consolidada, as estratégicas objecções ideológicas e as reivindicações patrióticas em prol da «nacionalização da arte», assunto em agenda desde o século XIX. No entanto, é certo que, traçado este quadro geral, encontramos em cada país condicionantes que conferiram ao percurso da arquitectura moderna variantes e especificidades nacionais.

Em Portugal, o modernismo não foi rejeitado em bloco, mas cedo se reivindicou a necessidade de o vestir «à portuguesa», de o «embrulhar» com papel de história e tradição. Dada a incapacidade ou a inconveniência de se realizar uma síntese crítica entre ambos, assistimos a uma autêntica «colagem» de elementos-símbolos aos ditos "caixotes" funcionais. A linguagem clássica foi, neste âmbito, apenas uma das «cascas» possíveis, logicamente reservada a tipologias-pilares do regime, carentes de uma sacralização capaz de as converter em entidades legitimadoras.

A terminar, o modo como os arquitectos lidaram com as linguagens moderna e historicista não pode ser concebido como uma evolução linear que parte da adopção da primeira até à sua substituição, voluntária ou forçada, pela segunda. As décadas de 1920 a 1940 mostram-nos como, ao invés de serem opostos, estes dois códigos linguísticos e simbólicos se complementaram. De facto, a sobrevivência de cada um passou por uma cedência ao outro, revelando que a pretensa orfandade do primeiro encontrou no segundo um bom padrinho. A «selecção natural» em arte é, como nas espécies, um fenómeno de adaptações sucessivas. Por isso, o conflito entre modernismo e historicismo é menos a luta entre presente e passado e mais o confronto entre duas formas de progresso: uma rectilínea e outra cíclica ${ }^{82}$. A nós, historiadores, cabe-nos o desafio intrincado, por isso interessante, de efectuar o rastreio destes processos híbridos, provando, uma vez mais, que a complexidade da realidade ultrapassa claramente a rigidez das categorias estilísticas.

\footnotetext{
“Cfr. M. Tafuri, 1988, p. 35-36, 55-56.

«' Cfr. J. Le Goff, 2000, p. 168.

${ }^{82}$ Cfr. M. Eliade, 1981 ; J. Le Goff, 2000; F. Catroga, 2003.
} 


\section{Documentação e bibliografia}

ACCIAIUOLI, Margarida, Os anos 40 em Portugal: o País, o regime e as artes. «Restauração»e «celebração», Lisboa, 1991, (policopiado), vol. I.

ARGAN, Giulio, Arte moderna. Do Iluminismo aos movimentos contemporâneos

(trad. do italiano), São Paulo, Companhia das Letras, 1992,4. a edição.

Arquitectura, [1927-1938].

A Arquitectura Portuguesa, [1930-1940].

ARTHUR, Judith Carmel, Bauhaus, Londres, Kliczkowski Publisher, 2000.

AXIAL, “A liberdade na arte”, A Arquitectura Portuguesa, III série, n. ${ }^{\circ}$ 9,

Dezembro de 1935, p. 9.

AXIAL, "No mundo da arte. Perguntas embaraçosas", A Arquitectura Portuguesa,

II série, n. ${ }^{\circ}$ 10/11, Outubro/Novembro de 1934, p. 112.

BENEVOLO, Leonardo, Historia de la arquitectura moderna (trad. do italiano),

Barcelona, Gustavo Gili, 1987, 6. ${ }^{\text {a }}$ edição.

BOURDIEU, Pierre, O poder simbólico (trad. do francês), Lisboa, Difel, 1989.

Cadernos da Revolução Nacional. Portugal de ontem. Portugal de hoje. Portugal de amanhã, Lisboa, SPN, s.d.

Catorze anos de Política do Espírito, Lisboa, SNI, 1948.

CATROGA, Fernando, Caminhos do fim da história, Coimbra, Quarteto, 2003.

CHUECA GOITIA, Fernando, Historia de la arquitectura occidental, Madrid,

Dossat Bolsillo, 1985, vol. IX.

CHUECA GOITIA, Fernando, Protótipos na arquitectura greco-romana e a sua influência no mundo ocidental (trad. do espanhol), Lisboa, Ulmeiro, 1996.

CIRIO, Alexandre, La estética delfranquismo, Barcelona, Gustavo Gili, 1977.

COLAÇO, Ribeiro, "Nacionalismo e lógica", A Arquitectura Portuguesa, III série, n. ${ }^{\circ} 38$, Maio de 1938, p. 9.

1 Congresso Nacional de Arquitectura. Relatório da Comissão Executiva. Teses, conclusões e votos do congresso, Lisboa, Sindicato Nacional dos Arquitectos, 1948.

CORREIA, Maximino, Ao serviço da Universidade de Coimbra: 1939-1960,

Coimbra, Por Ordem da Universidade, 1963.

COSTA, Francisco, "Por urna arquitectura própria. A arquitectura moderna", Arquitectura, Ano IV, n. ${ }^{\circ}$ 20, Agosto/Setembro de 1931, p. 80.

DORFLES, Gillo, A arquitectura moderna (trad. do italiano), Lisboa, Edições 70, 1986.

ELIADE, Mircea, O mito do eterno retomo. Arquétipos e repetição (trad. do francés), Lisboa, Edições 70,1981. 
“Entrevista a Raúl Lino”, Diário de Lisboa, Ano 13. „,n. ${ }^{\circ 3984,15}$ de Dezembro de 1933, p. 3.

Entrevistas de Antonio Ferro a Solazar, Lisboa, Parceria A. M. Pereira, 2003.

"Façam-se casas portuguesas em Portugal", A Arquitectura Portuguesa, III série, n. ${ }^{\circ}$ 46, Janeiro de 1939, p. 9.

FERNANDES, José Manuel, “Obras públicas", ROSAS, Femando e BRITO, José Brandão de (dir.), Dicionário de historia do Estado Novo, Lisboa, Círculo de Leitores, 1996, vol. II, p. 676-679.

FERNANDES, José Manuel, Português Suave. Arquitecturas do Estado Novo, Lisboa, IPPAR, 2003.

FERRO, António, Solazar. O homem e a sua obra, Lisboa, Empresa Nacional de Publicidade, 1933.

FERRO, António, Museu de arte popular, Lisboa, SNI, 1948.

FERRO, António, Arte Moderna, Lisboa, SNI, 1949.

FOUCAULT, Michel, Microfísica do poder (trad. do francês), São Paulo, Graal, 2002, 17. a edição.

FRAMPTON, Kenneth, Historia crítica de la arquitectura moderna (trad. do inglés), Barcelona, Gustavo Gili, 1987, 3. a edição.

FRANÇA, José-Augusto, $A$ arte em Portugal no século XX: 1911-1961, Venda Nova, Bertrand Editora, 1991, 3. ${ }^{\mathrm{a}}$ edição.

GARNIER, Christine, Férias com Solazar (trad. do francês), Lisboa, Parceria A. M. Pereira, 2002, 3a edição.

HAFTM ANN, Wemer, Banned andpersecuted: dictatorship of art under Hitler, Colónia, DuMont Buchverlag, 1986.

HITLER, Adolf, Mein Kampf. A minha luta (trad. do alemão), Lisboa, Hugin Editores, 1998.

JENCKS, Charles, Movimentos modernos em arquitectura (trad. do inglês), Lisboa, Edições 70, 1987.

KOSTOF, Spiro, Historia de la arquitectura (trad. do inglês), Madrid, Alianza, 1996, vol. 3.

LE GOFF, Jacques, Historia e memoria (trad. do italiano), Lisboa, Edições 70, 2000, vol. I.

LIBERTUS, "Questões de Arte", A Arquitectura Portuguesa, II série, n. ${ }^{\circ} 8$, Agosto de 1932, p. 63-64; n. ${ }^{\circ}$ 9, Setembro de 1932, p. 72.

LUNATCHARSKY, A., As artes plásticas e a política na U.R.S.S. (trad. do russo), Lisboa, Editorial Estampa, 1975.

MARIA MONTANER, Josep, La modernidad superada. Arquitectura, arte y pensamiento del siglo XX, Barcelona, Gustavo Gili, 1997. 
MICHAUD, Éric, Un art de Véternité. L'image et le temps du nationalsocialisme, Paris, Gallimard, 1996.

MINNAERT, Jean-Baptiste, "Monumentalidade (Nova). De Londres a Moscovo, o triunfo do novo classicismo", FERNANDES, Gabriela (coord.), ABCedário dos Anos 30, Lisboa, Rebom, 2003, p. 89.

"Monumentality and the city", The Harvard Architecture Review, MIT Press, 1984, vol. IV.

NUNES, Antonio Manuel, Espaços e imagens da justiça no Estado Novo: templos da justiça e arte judiciária, Coimbra, Minerva, 2003.

Ó, Jorge Ramos do, "Ferro, Antonio Joaquim Tavares", ROSAS, Femando e BRITO, José Brandão de (dir.), Dicionário de historia do Estado Novo, Lisboa, Círculo de Leitores, 1996, vol. I, p. 355-357.

Ó, Jorge Ramos do, Os anos de Ferro. O dispositivo cultural durante a "Política do Espirito " 1933-1949: ideologia, instituições, agentes epráticas, Lisboa, Editorial Estampa, 1999.

OCKMAN, Joan (edição de), Architecture, criticism, ideology, Princeton, Princeton Architectural Press, 1985.

PAUL, Jürgen, "Henry-Russell Hitchcock. Philip Johnson. The International Style: Architecture Since 1922", Teoria da arquitectura do Renascimento até aos nossos dias. 117 tratados apresentados em 89 estudos, Kõln, London, Los angeles, Madrid, Paris, Tokyo, Taschen, 2003, p. 715-716.

PEREIRA, Nuno Teotónio e FERNANDES, José Manuel, “A arquitectura do fascismo em Portugal”, O fascismo em Portugal. Actas, Lisboa, A Regra do Jogo, 1982, p. 533-551.

PEVSNer, Nikolaus, Panorama da arquitectura ocidental (trad. do inglés), São Paulo, Martins Fontes, 1982.

PORTAS, Nuno, "A evolução da arquitectura moderna em Portugal: uma interpretação", ZEVI, Bruno, Historia da arquitectura moderna (trad. do italiano), Lisboa, Arcádia, 1973, vol. II, p. 687-744.

PORTELA JÚNIOR, Severo, Arte Antiga. Arte moderna. Relatório apresentado à Junta de Educação Nacional, Lisboa, Imprensa Lucas \& C. a, 1936.

ROSMANINHO, Nuno, O princípio de uma "revolução urbanística " no Estado Novo: os primeiros programas da cidade universitária de Coimbra (1934-1940), Coimbra, Minerva Editora, 1996.

Rosmaninho, Nuno, O Poder da Arte. O Estado Novo e a cidade universitária de Coimbra, Coimbra, 2001, (policopiado), vol. I.

SCHIRó, Luís Bensaja dei, O futurismo italiano. Estética, ideologia, fascismo, Lisboa, Editorial Caminho, 1999. 
SILVA, Umberto, Arte e ideología delfascismo, Valência, Femando Torres, 1975. SOLA-MORALES, Ignasi de, Inscripciones, Barcelona, Gustavo Gili, 2003.

SPEER, Albert, O III Reich por dentro. Memorias de Albert Speer (trad. do alemão), Lisboa, Livros do Brasil, 1969, vol. I.

SUMMERSON, John, A linguagem clássica da arquitectura (trad. do inglés), São Paulo, Martins Fontes, 1994.

TAFURI, Manfredo, Teorias e historia da arquitectura (trad. do italiano), Lisboa, Editorial Presença, 1988.

TARKHANOV, Alexei e KAVTARADZE, Sergei, Stalinist architecture, London, Laurence King, 1992.

TELMO, José Cottinelli, Os novos edificios públicos, Lisboa, C.M.L., 1936.

TELMO, José Cottinelli, "Arquitectura Nacional - Arquitectura internacional", I Congresso Nacional de Arquitectura. Relatório da Comissão Executiva. Teses, conclusões e votos do congresso, Lisboa, Sindicato Nacional dos Arquitectos, 1948, p. 61-73.

TINTELNOT, Hans, Do neoclassicismo à arte moderna (trad. do alemão), Lisboa, Editorial Verbo, 1972.

TOSTÕES, Ana, Os verdes anos na arquitectura portuguesa dos anos 50, Porto, Faculdade de Arquitectura da Universidade do Porto, 1997, 2. a edição.

TOSTÕES, Ana, "Ministério das Obras Públicas", ROSAS, Femando e BRITO, José Brandão de (dir.), Dicionário de historia do Estado Novo, Lisboa, Círculo de Leitores, 1996, vol. II, p. 585-598.

TOSTÕES, Ana, "Monumentalidade, obras públicas e afirmação da arquitectura do Movimento Moderno: o protagonismo da DGEMN na construção dos grandes equipamentos nacionais”, ALÇADA, Margarida e GRILO, Maria Inácia Teles (coord.), Caminhos do Património, Lisboa, DGEMN, 1999, p. 133-150.

VALE, Lawrence J., Architecture, power, and national identity, New Haven/ /London, Yale University Press, 1992.

VALÉRY, Paul, Apontamentos. Arte, literatura, politica \& outros (trad. do fiancés), Lisboa, Editora Pergaminho, 1994.

ZEVI, Bruno, História da arquitectura moderna (trad. do italiano), Lisboa, Arcádia Editora, 1970, vol. I.

ZEVI, Bruno, A linguagem moderna na arquitectura (trad. do italiano), Lisboa, Publicações Dom Quixote, 1984.

ZEVI, Bruno, Giuseppe Terragni (trad. do italiano), Barcelona, Gustavo Gili,

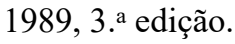

